\title{
Jewish on Their Own Terms
}





\section{Jewish on Their Own Terms}

How Intermarried Couples Are Changing American Judaism

JENNIFER A. THOMPSON

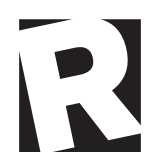

RUTGERS UNIVERSITY PRESS

NEW BRUNSWICK, NEW JERSEY, AND LONDON 
Library of Congress Cataloging-in-Publication Data

Thompson, Jennifer A. 1976-

Jewish on their own terms : how intermarried couples are changing American Judaism / Jennifer Thompson

pages $\mathrm{cm}$

Includes bibliographical references and index.

ISBN 978-0-8135-6282-7 (hardcover : alk. paper)-ISBN 978-0-8135-6281-0

(pbk. : alk. paper)-ISBN 978-0-8135-6283-4

1. Interfaith marriage-United States. 2. Intermarriage-United States. 3. JewsUnited States-Identity. 4. Marriage-Religious aspects-Judaism. 5. Jews-United States-Cultural assimilation. 6. Judaism-United States-21st century. I. Title HQ1031.T46 2014

305.892'4073-dc23

2013010366

A British Cataloging-in-Publication record for this book is available from the British Library.

Copyright (C) 2014 by Jennifer A. Thompson

All rights reserved

No part of this book may be reproduced or utilized in any form or by any means, electronic or mechanical, or by any information storage and retrieval system, without written permission from the publisher. Please contact Rutgers University Press, 106 Somerset Street, New Brunswick, NJ 08901. The only exception to this prohibition is "fair use" as defined by U.S. copyright law.

Visit our website: http://rutgerspress.rutgers.edu

Manufactured in the United States of America 
For Suzette Cohen, to whom so many Jewish families are grateful 
